\title{
Effects of Four Different Food Additives on the Oxidative Stress Markers of Wistar Albino Rats
}

\author{
Ifemeje J.C. ${ }^{*}$, Ezeonyemalu U.E. ${ }^{1}$, Egbuna C. ${ }^{2}$, Olisah M.C. ${ }^{3}$, Ifemeje M.O. ${ }^{1}$ \\ ${ }^{1}$ Department of Biochemistry, Faculty of Natural Sciences, Chukwuemeka Odumegwu Ojukwu University, \\ Anambra State- 431124, Nigeria. \\ ${ }^{2}$ Nutritional Biochemistry and Toxicology Unit, World Bank Africa Centre of Excellence, Centre for Public \\ Health and Toxicological Research (ACE-PUTOR), University of Port-Harcourt, Rivers State, Nigeria. \\ ${ }^{3}$ Department of Medical Biochemistry, Faculty of Basic Medical Sciences, Chukwuemeka Odumegwu Ojukwu \\ University, Anambra State- 431124, Nigeria. \\ * Corresponding author email: jcifemeje@gmail.com \\ Received: 27 September 2019 / Revised: 02 November 2019 / Accepted: 23 November 2019 / Published: 24 November 2019
}

\begin{abstract}
This work investigated the effects of food additives on the oxidative stress markers and liver marker enzymes. Food additives are products added to the basic food stuff with an aim of improving its flavor, aspect, texture, color, taste, and value. Thirty (30) Wistar rats were divided into five groups of six rats each. Group A received a daily dose of distillated water and normal rat pellet, Group B, C, D and E received $20 \mathrm{mg} / \mathrm{kg}$ body of Aspartame, Sodium Benzoate, Sodium nitrite and sodium sulfite respectively. The duration for exposure of these animals to food additives was 30 days and the groups were observed daily for general conditions. At the end of feeding the animals, blood samples were collected and analyzed. The result of the analysis showed that ALT significantly $(\mathrm{p}<0.05)$ increased with sodium nitrite and sodium sulfite while ALP increased significantly $(\mathrm{p}<0.05)$ with sodium sulphite. The oxidative stress biomarker, catalase showed a significant increase with sodium benzoate and sodium sulphite. The results revealed that the food additives are injurious to the animals. The toxicity of the food additives studied at $20 \mathrm{mg} / \mathrm{kg}$ are in the order of Sodium nitrite > Sodium benzoate $>$ Sodium sulphite $>$ Aspartame.
\end{abstract}

Keywords: Food additives, oxidative stress, marker enzymes, sodium nitrite, aspartame, sodium sulphite, Sodium benzoate.

\section{Introduction}

There has been a growing concern about the safety of food additives which are products added to the basic food stuff with the aim of improving its flavor, aspect, texture, color, taste, and value [1]. The food additives overtime has been helpful in meeting the needs of growing population during production and presentation of plentiful, tasty and nutritious food [2]. There have been great advances in food preparation and preservation in the last century. However, over half of the foods bought in a typical supermarket are packaged or prepared in such a way that they contain chemicals and additives that are known to harm either human or laboratory animals [3]. Food additives are also xenobiotics to which humans are exposed to through food. The liver is usually the site of its metabolism. The metabolism results to biologic effects which may include pharmacologic response, toxicity, immunological reactions, and cancer. In the human body, some substances such as free radicals in the form of reactive oxygen species (ROS) or reactive nitrogen species (RNS) are continuously produced as byproducts of normal metabolism [4, 5]. The increase in amount of ROS or RNS is associated with numerous biochemical and pathophysiological alterations including lipid 
peroxidation, DNA damage, aging process, hepatic damage, cardiovascular diseases and cancer [6]. This increase can be aggravated with the intake of substances capable of inducing oxidative stress. Although in natural food sources, there exist vital antioxidant substances capable of annulling these effects [7]. Some commonly used additives are aspartame (ASP), sodium benzoate, sodium nitrite and sodium sulphite. This study evaluated this commonly food additives on the oxidative stress markers and liver marker enzymes of male Wistar albino rats.

\section{Materials and Methods}

The four food additives Aspartame (E951), Sodium benzoate (E211), Sodium nitrite (E250), and Sodium sulfite (E221) used are all in solid form. These samples were sourced from Qingdao FTZ United International Inc., Qingdao China, K.D. Feddersen Holding GmbH Hamburg Germany, Lomberg GmbH Mulheim Germany and CG Chemikalien GmbH \& Co. KG Laatzen, Germany respectively. Thirty male Wistar albino rats within 6-7 weeks with average weight of $160 \mathrm{~g}$ were obtained from Chris animal farm Ifite, Awka, Anambra state and were before commencement. The animals were allowed access to standard rat chows and water ad libitum. Ethical clearance was obtained from the ethical committee and handled in accordance with the US institute of health [8]. The $\mathrm{LD}_{50}$ of the additives were determined in mice using the Lorke's method. The animals were administered with the additives and monitored for 24 hours for signs and symptoms such as excitation, paw licking, increased respiratory rate, writhing, convulsion and death. $\mathrm{LD}_{50}$ was calculated.

\subsection{Experimental Design}

Thirty male Wistar albino rats were distributed into five equal groups. Each group contains six apparently healthy male albino Wistar rats and was grouped according to the following scheme;

Group A: This first group was normal control group. Rats of this group were fed with distilled water and normal rat pellet.

Group B: Rats in this group were fed with $20 \mathrm{mg} / \mathrm{kg}$ body weight of aspartame and $90 \mathrm{~g}$ normal rat feed daily.
Group C: This group of rats received 20 $\mathrm{mg} / \mathrm{kg}$ body weight of sodium benzoate and $90 \mathrm{~g}$ normal rat feed daily.

Group D: This group of rats received 20 $\mathrm{mg} / \mathrm{kg}$ body weight of sodium nitrite and $90 \mathrm{~g}$ normal rat feed daily.

Group E: This group of rats received 20 $\mathrm{mg} / \mathrm{kg}$ body weight of sodium sulfite and $90 \mathrm{~g}$ normal rat feed daily.

The Additives were mixed with normal rat chow and were fed to rats ad libitum. After 30 days of feeding period, the animals were fasted overnight and sacrificed under anesthesia (chloroform). Blood samples were drawn from cardiac aorta puncture using $10 \mathrm{~mL}$ hypodermic syringe. Serum was obtained by centrifugation at $3000 \mathrm{rpm}$ for $10 \mathrm{mins}$ and then stored in a refrigerator at $0-4{ }^{\circ} \mathrm{C}$ prior to biochemical analysis.

\subsection{Determination of Glutathione Peroxidase Activity (GPx)}

GPx activity was determined based on the method of Paglia and Valentine [9]. GPx catalyzes the oxidation of glutathione (GSH) by cumene hydroperoxide. In the presence of Glutathione Reductase (GR) and NADPH, the oxidized glutathione reductase (GSSG) is readily converted to its reduced form with a corresponding oxidation of NADPH to $\mathrm{NADP}^{+}$. This results to a decrease in absorbance which is measured spectrophotometrically at $340 \mathrm{~nm}$.

\subsection{Determination of Catalase Activity}

About $4 \mathrm{ml}$ of the Hydrogen Peroxide was added to $2.5 \mathrm{ml}$ of phosphate buffer and $0.5 \mathrm{ml}$ of sample and mixed. A $\mathrm{ml}(1 \mathrm{ml})$ portion of the reaction mixture was added to $2 \mathrm{ml}$ of dichromate acetate reagent. The absorbance was read at $570 \mathrm{~nm}$.

\subsection{Serum Lipid Peroxide (Malondialdehyde)}

Malondialdehyde (MDA) was determined by Ohkawa et al. [10] using Spectrophotometer. An aliquot $0.1 \mathrm{ml}$ of the serum and $0.9 \mathrm{ml}$ of $\mathrm{H}_{2} \mathrm{O}$ was added $0.5 \mathrm{ml}$ of $25 \%$ TCA and then $0.5 \mathrm{ml}$ of $1 \%$ TBA in $0.3 \% \mathrm{NaOH}$, which was boiled for 40 minutes in water and cooled in $\mathrm{H}_{2} \mathrm{O}$. This was followed by the addition of $0.5 \mathrm{ml} 20 \%$ SDS 
(sodium dedocyl sulphate) and then mixed. The absorbance was read at 582 and $600 \mathrm{~nm}$.

\subsection{Liver Function Test}

Serum Alanine aminotransferase (ALT) and aspartate transaminase (AST) activity was determined as described by Reitman and Frankel [11] using colorimetric method, while Alkaline Phosphatase (ALP) was determined as described by Belfield and Goldberg [12].

\subsection{Statistical Analysis}

Results were expressed as mean \pm standard three replicate determinations. Statistical analysis was performed on data generated from the study using statistical package for social sciences (SPSS) software for windows, version 20.0. One-way analysis of variance was used to compare means of different groups. Statistical significance was observed at $\mathrm{P}<0.05$.

\section{Results and Discussion}

Food additives are usually being added to our daily diet to improve its flavor, taste, texture and color. For centuries now, food additives have been used in food preservation through pickling (with vinegar), salting, and the use of sulfur dioxide as with wines. Literature data showed that oxidative stress contributes to endothelial dysfunction by modulating Nitric oxide (NO) bioavailability in the microcirculation [13], among other deleterious consequences. The effects of the food additives on the oxidative stress marker enzymes; glutathione peroxidase and catalase showed slight decrease in glutathione peroxidase levels which are not significant (Fig. 1). However, an increase was observed for levels of catalase suggesting that the food additives caused the production of hydrogen peroxides which caused the stimulation of the production of catalase (Fig. 2). The highest concentration of catalase was observed for group administered sodium benzoate. For the levels of malondialdehyde concentration, it was observed that group administered sodium benzoate and sodium sulfite had higher concentration (Fig. 3). Malondialdehyde is a product of lipid peroxidation. So, an elevated level suggests oxidative stress.

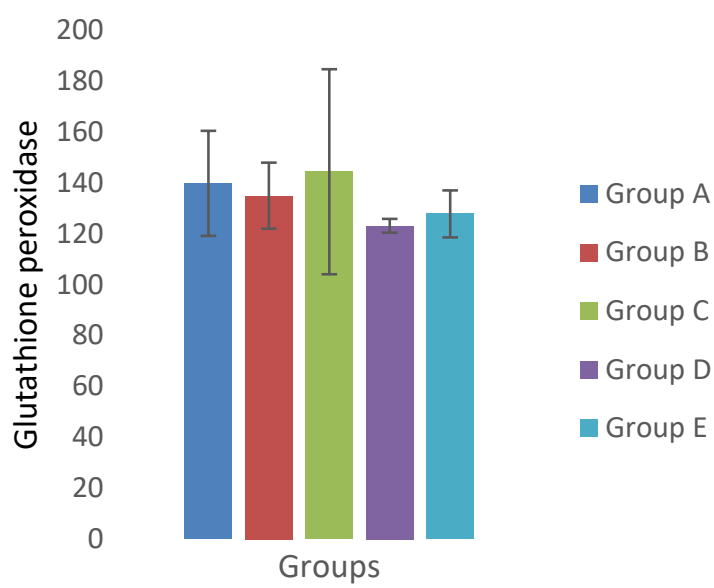

Figure 1: Glutathione peroxidase activity of the rats fed with different food additives

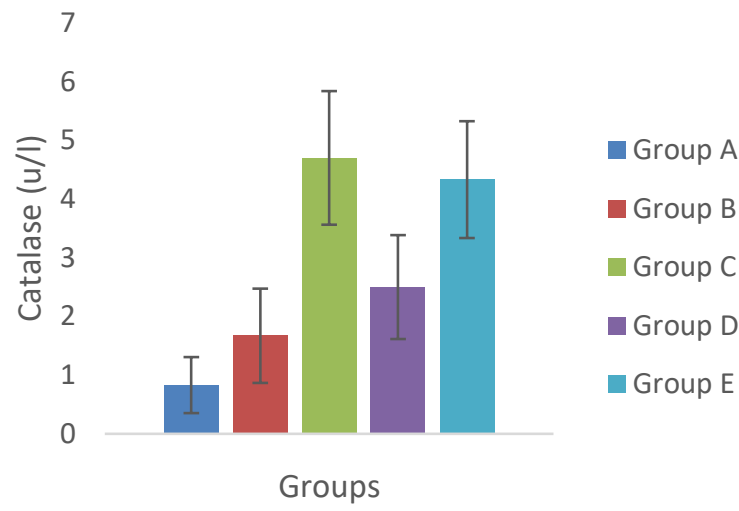

Figure 2: Catalase activity of the rats fed with different food additives.

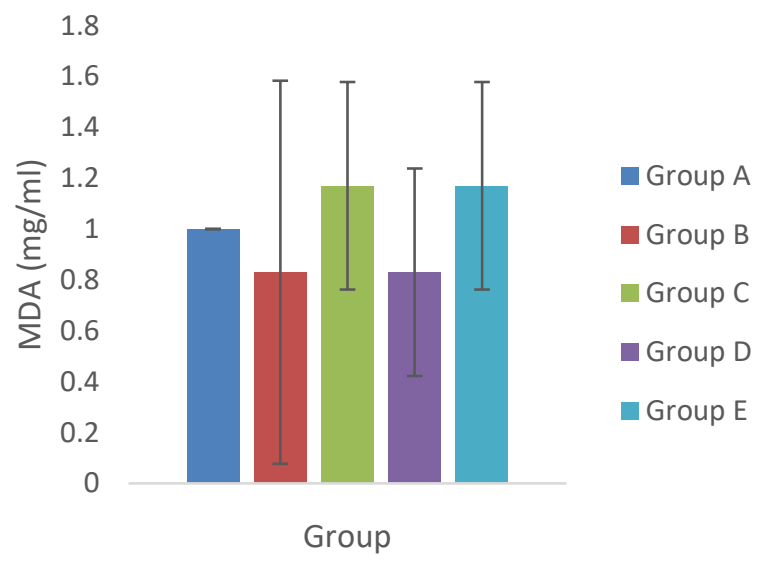

Figure 3: Malondialdehyde activity of rats fed with different food additives.

Group A: Group fed normal rat pellet and distilled water;

Group B: Group fed $20 \mathrm{mg} / \mathrm{kg}$ body weight of Aspartame;

Group C: Group fed $20 \mathrm{mg} / \mathrm{kg}$ body weight of sodium benzoate and

normal rat feed daily;

Group D: Group fed $20 \mathrm{mg} / \mathrm{kg}$ body weight of sodium nitrite and normal rat feed daily;

Group E: Group fed $20 \mathrm{mg} / \mathrm{kg}$ body weight of sodium sulfite and normal rat feed daily. 
Determination of AST and ALT in serum is largely used in the assessment of liver damage [14]. Membrane damage to the liver causes the leakage of enzymes into the blood which could then be monitored in the serum. High level of serum AST and ALT is usually a clinical indicator of liver damage [15]. In the evaluation of serum marker enzymes for hepatotoxicity, there was an elevation in ALT, AST and ALP of male Wistar rat groups fed food additives when compared to the control (Fig. 4, 5 and 6). The result is in accordance with the findings of Eman et al. [16]; Mahmoud et al. [17]; Etim et al. [18]. The highest level of ALT was found in group fed sodium nitrite and sodium sulphite. The elevation in the activities of these enzymes reflects a state of hepatocyte injury [19]. It also indicates an enhanced permeability, damage or necrosis of hepatocytes. According to Wang and Srivastava [15], these alterations in enzyme levels may depend on exposure and dosage. It noted that sodium benzoate caused derangement of liver function as revealed by significant increase of serum ALT and AST as well as significant decrease of these enzymes in the liver. The highest level of AST was found in the group administered sodium nitrite. This is an indication that sodium nitrite could also be injurious to muscle cells and liver cells. Increase in ALP as in case of sodium sulfite suggests an increase in lysosomal mobilization and cell necrosis due to toxicity [20]. This is similar with the findings of Eman et al. [16]. Based on their findings, aspartame treatment increased the levels of Nitric oxide NO and Lipid peroxidase (LPO) in erythrocytes. The increased levels of Lipid peroxidase LPO and Nitric oxide $\mathrm{NO}$ are taken as direct evidence of oxidative stress [21]. This alteration after ASP administration may be attributable to methanol; its metabolites. Methanol is primarily metabolized by oxidation to form- aldehyde and then to formate. This also results to formation of superoxide ion and $\mathrm{H}_{2} \mathrm{O}_{2}$ $[21,22]$. Lipid peroxidation in cell membranes cause damages to polyunsaturated fatty acids and hence reduce membrane fluidity.

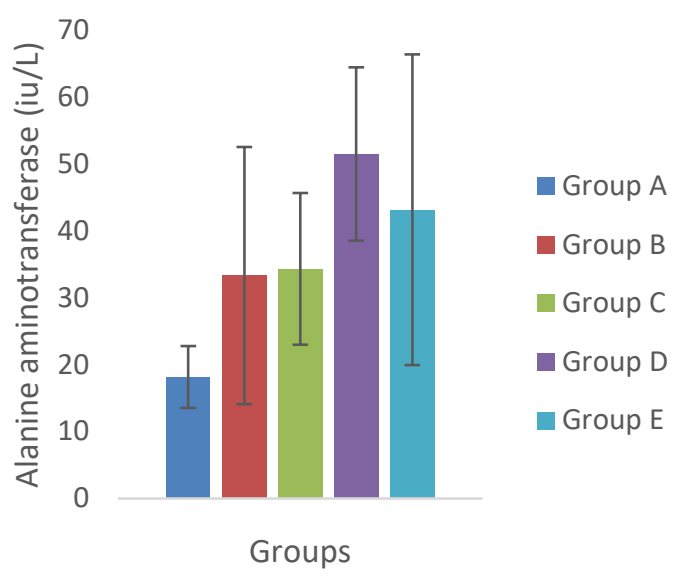

Figure 4: Alanine aminotransferase (ALT) of the rats fed with different food additives

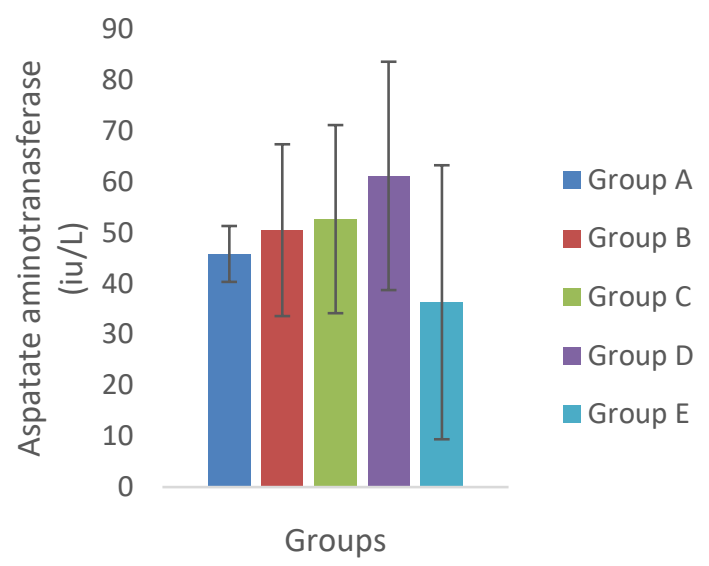

Figure 5: Aspartate aminotransferase (AST) of the rats fed with different food additives

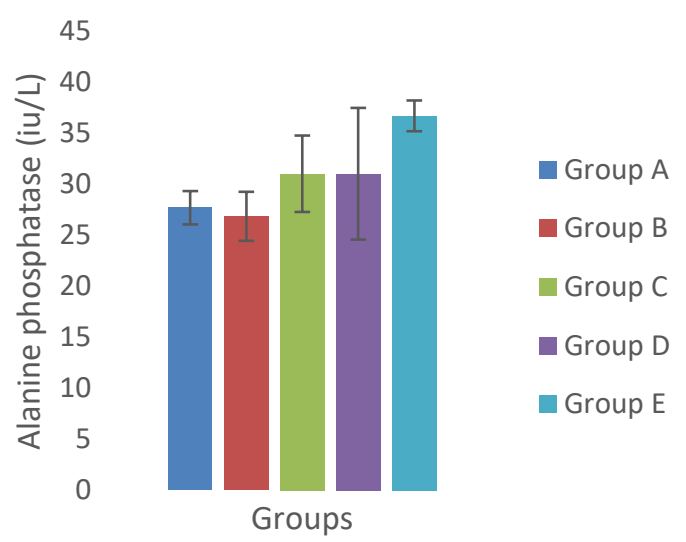

Figure 6: Alanine phosphatase (ALP) of the rats fed with different food additives.

Group A: Group fed normal rat pellet and distilled water; Group B: Group fed $20 \mathrm{mg} / \mathrm{kg}$ body weight of Aspartame; Group C: Group fed $20 \mathrm{mg} / \mathrm{kg}$ body weight of sodium benzoate and normal rat feed daily;

Group D: Group fed $20 \mathrm{mg} / \mathrm{kg}$ body weight of sodium nitrite and normal rat feed daily;

Group E: Group fed $20 \mathrm{mg} / \mathrm{kg}$ body weight of sodium sulfite and normal rat feed daily 
Ifemeje et al., Int. Ann. Sci.; Vol. 9, Issue 1, pp: 46-51, 2020

Prokic et al. [23], observed a significant increase in ALT, AST and LDH activities in ASP-treated rats. The increased levels of serum enzymes indicated an enhanced damage or necrosis of hepatocytes. The disturbance in the transport function of the hepatocytes because of hepatic injury may result to leakage of enzymes from cells due to increased lipid peroxidation. It is likely that ASP induces biochemical changes in the liver. These alterations in enzyme levels may depend on exposure time and dose.

\section{Conclusion}

The result of the study has shown that administration of food additives may induce oxidative stress and caused a number of changes in the liver marker enzymes. This suggested that the food additives studied are injurious to the health and must be used with caution. Comparatively, the food additives studied showed that Sodium nitrite exerted more changes on oxidative and liver marker enzymes, followed by Sodium benzoate, Sodium Sulphite and Aspartame. However, there is need to apply caution when selecting and applying additives to our food.

\section{Declarations}

\subsection{Acknowledgment}

The authors wish to appreciate the support of the staff of Department of Biochemistry, Chukwuemeka Odumegwu Ojukwu University, Uli Campus.

\subsection{Ethical Approval}

Ethical approval letter was obtained from the IRB with reference no 0000200100 .

\subsection{Competing Interests}

The authors declare that no conflict of interest exist in this publication.

\section{How to Cite this Article:}

I. C, E. E, C. Egbuna, O. C, and I. O, "Effects of Four Different Food Additives on the Oxidative Stress Markers of Wistar Albino Rats", Int. Ann. Sci., vol. 9, no. 1, pp. 4651, Nov. 2019. doi:10.21467/ias.9.1.46-51

\section{References}

[1] H. Imane, B. Said, S. Faiza, B. Fatima, A. Mohammed B. Mohamed, Z. Jouhar B. Zolikha M. Hassane, E. Saalaoui, E. A 90 day oral toxicity study of Tartrazine, a synthetic food dye, in wistar rat. International Journal of Pharmacy and Pharmaceutical Science, vol. 3, issue 3, pp. 159-169, 2011.

[2] Y. Gao, C. LI, J. Shen, H. Yin, X. An, H. Jin. Effect of food azo dye tartrazine on learning and memory functions in mice and rats, and the possible mechanisms involved. $J$ Food Sci., vol 76, issue 6, pp. 125-129, 2011.

[3] S.A. Mohammed, N.A. Elkattan. Assessment of the changes in some diagnostic parameters in male albino rats fed on an Azo Dye. International journal of environmental science and engineering, vol 4, pp. 85-92, 2013.

[4] C. Egbuna, Antioxidants and Phytochemicals. In: Phytochemistry, Volume 2: Pharmacognosy, Nanomedicine, and Contemporary Issues. Egbuna, C. et al. (Eds). Apple Academic Press: New York. Pp. 131-146, 2018.

[5] J.C. Ifemeje, S.C. Udedi, A.U. Okechukwu, A.C. Nwaka, C.B. Lukong, I.N. Anene, C. Egbuna, I.C. Ezeude. Determination of Total Protein, Superoxide Dismutase, Catalase Activity and Lipid Peroxidation in Soil Macrofauna (Earthworm) from Onitsha Municipal Open Waste Dump. Journal of Scientific Research \& Reports, vol 6, issue 5, pp. 394-403, 2015.

[6] C. Lopez-alarcona, A. Denicola. Evaluating the Antioxidant Capacity of Natural Products: A Review on Chemical and Cellular-Based Assays. Anal Chim. Acta. Vol 763, pp. 1-10, 2013.

[7] C. Egbuna, J.C. Ifemeje, T.L. Kryeziu, M. Mukherjee, H. Shah, G.M.N. Rao, L.J.F.J. Gido, H. Tijjani (2018, Dec). Introduction to phytochemistry. In: Phytochemistry, volume 1: Fundamentals, Methods, and Applications. C. Egbuna. et al. (Eds). Apple Academic Press: New York. Pp. 3-35.

[8] M.C. Olisa, O.U. Ilechukwu, J.C. Ifemeje, C.C. Offor. Effect of vitamin $\mathrm{C}$ against calcium carbide induced hepatotoxicity. Trop. J. appl. Nat. Sci. vol 2, Issue 1, pp. 74-77, 2017.

[9] D.E. Paglia, W.N. Valentine. Studies on the quantitative and qualitative characterization of erythrocyte glutathione peroxidase. J. Lab Clin Med. Vol 70 Issue 1, pp. 158 - 69, 1967.

[10] H. Ohkawa, N. Ohishi, K. Yagi. Assay for lipid peroxides in animal tissues by thiobarbituric acid reaction. Anal Biochem. Vol. 95, Issue 2, $351-8,1979$.

[11] S. Reitman, S. Frankel. A colorimetric method for determination of serum glutamic oxaloacetic and glutamic pyruvic transaminases. American Journal of Clinical Pathology, vol 28, pp. 56-62, 1957.

[12] A. Belfield, D.M. Golbderg. Colorimetric determination of alkaline phosphatase (ALP) activity Enzymes In: $J$. Clin. Chem. Clin. Biochem. Vol 8, P. 561, 1971.

[13] K.B. Pandey, S.I. Rizvi. Markers of oxidative stress in erythrocytes and plasma during aging in humans. Oxid. Med. Cell. Longev. 3: 2-12, 2010.

[14] D.W. Moss, S.B. Rosalki. Enzyme tests in diagnosis. Edward Arnold. London, pp. 187-196, 1996.

[15] W. Wang, S. Srivastava. Serological markers. In Breslow, Lester. Encyclopedia of Public Health. New York. Macmillan, USA, pp. 1088-1090, 2002. 
[16] S.A. Eman, A.A. Hanan, M.M. Basant, N.A. Eman. Effect of food additives (Monosodium glutamate \& Sodium nitrite) on some biochemical parameters in albino rats. International Journal of bioassays. Vol 67, Issue 2, pp. 605- 613, 2014.

[17] A.A.T. Mahmoud, G.M. Hassan, A.M.S. Hassan, A.K. Mohammed, A. Latif, M.F. Ramadan. Demostrating adverse effects of a common food additive (sodium sulfite) on biochemical cytological and histopathological parameters in tissues of albino wistar rats. European Journal of Integrative medicine. Vol 7, Issue 3, pp. 234242, 2015.

[18] O.E. Etim, E.O. Fabrombi, I.F. Usoh, E.J. Akpan. The protective effect of alovera Juice on lindare induced hepatotoxicity and genotoxicity. J. Pharmaceut. Sci. vol 19, pp. 337-340, 2006.

[19] L.S. Pari, A. Arumugam. Effect of grape (VitisviniferaL.) leaf extract on alcohol-induced oxidative stress inrats. Food and Chemical Toxicol., vol. 46, pp. 1627-1634, 2008.

[20] S.A.Kalender, F. Ogutcu, P. Acikgoz, Y. Kalender. Diazi'non-induced hepatotoxicity and protective effect of vitamin $\mathrm{E}$ on some biochemical indices and ultrastructural changes. Toxicol. Vol 211, pp. 197-206, 2005.

[21] P. Humphries, E. Pretorius, H. Naudé. "Direct and indirect cellular effects of aspartame on the brain". European Journal of Clinical Nutrition. vol 62, Issue 4, 451-462, 2008.

[22] J.N. Parthasarathy, S.K. Ramasundaram, M. Sundaramahalingam, S.D. Pathinasamy. (2006) Methanol induced oxidative stress in rat lymphoid organs. J. Occup. Health. Vol 48, pp. 20-27, 2006.

[23] M. Prokic, A Stajn, Z. Saicic, Z. Effect of Aspartame on biochemical and oxidative parameters in rat blood. Archives of Biological Sciences. p. 542, 2015.
Publish your books with AIJR publisher-

$\checkmark \quad$ Publish with ISBN and DOI.

$\checkmark \quad$ Publish Thesis/Dissertation as Monograph.

$\checkmark \quad$ Publish Book Monograph.

$\checkmark \quad$ Publish Edited Volume/ Book.

$\checkmark \quad$ Publish Conference Proceedings

$\checkmark \quad$ Retain full copyright of your books.

Submit your manuscript at books.aijr.org

Publish your research article in AIJR journals-

$\checkmark \quad$ Online Submission and Tracking

$\checkmark$ Peer-Reviewed

$\checkmark \quad$ Rapid decision

$\checkmark \quad$ Immediate Publication after acceptance

$\checkmark \quad$ Articles freely available online

$\checkmark \quad$ Retain full copyright of your article.

Submit your article at journals.aijr.in 